\title{
CROHN S DISEASE AND ACNE FULMINANS AS ASSOCIATED DISODERS (CASE REPORT)
}

\author{
Pecova K, jr ${ }^{1}$, Vorcakova K. ${ }^{1}$, Horakova M. ${ }^{2}$, Vojarova L. ${ }^{3}$ \\ ${ }^{1}$ Departments of Dermatovenerology; ${ }^{2}$ Clinic of Gastroenterology; ${ }^{3}$ Clinic of Pediatrics, \\ Comenius University, Jessenius Faculty of Medicine in Martin and University Hospital in Martin, Slovakia
}

\section{A bs tract}

The authors are presenting a rare case of recurrent acne fulminans (AF) in man with Crohn's disease (CD). First attak of $\mathrm{AF}$ as associated disorder was observed at the age of 21 with positivity rheumatoid factor (28.0 U/ml), Creactive protein $(86.7 \mathrm{~m} / 1)$, ANA (1:160), p-ANCA (1:40) and 82 erythrocyte sedimentation rate/1 hour. The second attak of AF was observed after the 4 th infliximab $(5 \mathrm{mg} / \mathrm{kg})$ administration, with azathioprine (100mg/day), with positivity Epstein-Barr (EBV Real Time PCR - 1835 copies/ml). The effect of AF therapy was observed after methylprednisolone $(0.5-1.0 \mathrm{mg} / \mathrm{kg} /$ day $)$ with isotretinoin $(0.2-1.0 \mathrm{mg} / \mathrm{kg} /$ day $)$ administration, with continual infliximab administration.

Key words: Acne fulminans, morbus Crohn, infliximab, azathioprine

\section{INTRODUCTION}

Pathogenesis of AF is unknown. Hormonal, genetic disposition, delayed hypersensitivity response to Propionibacterium acnes, immune complexes mediated mechanisms have been presumed $(1,2)$.

\section{CASE REPORT}

A 30-year-old man, BMI 23.76, BSA $1.96 \mathrm{~m}^{2}$, at 17 acne papulopustulosa, from $20 \mathrm{CD}$. At the age of 21 , having discontinued the methylprednisolone therapy, sudden AF, with fever $\left(>39^{\circ} \mathrm{C}\right)$, arthralgias, myalgias, had occured. At that time $4.0 \mathrm{~g} /$ day of the 5-ASA mesalazine, intravenous clindamycin $1800 \mathrm{mg} /$ day for 14 days, oral $900 \mathrm{mg} /$ day for $1 \mathrm{month}$, methylprednisolone $1.0 \mathrm{mg} / \mathrm{kg} /$ day, three weeks later $0.2 \mathrm{mg} / \mathrm{kg} / \mathrm{day}$, increased to $0.75 \mathrm{mg} / \mathrm{kg} /$ day of isotretinoin were administered. After the 3 months AF remission was observed, thus gradually reduction of methylprednisolone $(4 \mathrm{mg} /$ day) and isotretinoin (0.2mg/day) was undertaken.

At age of 26, the CD-fistulizing abscessing form developed. Subsequently, the 5-ASA mesalazine $(1.5 \mathrm{mg} /$ day) with methylprednisolone $(0.5 \mathrm{mg} / \mathrm{kg} /$ day), ciprofloxacin $(1.5 \mathrm{~g} /$ day), metronidazole $(750 \mathrm{mg} /$ day) and actiferrin had been adjusted, later infliximab $(5 \mathrm{mg} / \mathrm{kg})$ and azathioprine (150 mg/day) have been introduced.

The second episode of AF developed after the 4th infliximab administration (Figs.1,2). By the means of indirect immunofluorescence method were investigated ANA positivity (homogeneous core type), but c-ANCA negativity (anti-PR3; tab. 1). The microscopic haematuria, without proteinuria, and sterile urine have been detected. Normal values of the serum albumin, beta-2 microglobulin, immunocomplexes, immunoglobulins, creatinine, urea, antistreptolysin O, liver enzymes, amylase, lipid profile, glycaemia, minerals, negativity of HLA-B27, the Quantiferon-GOLD test, HIV, HBcAg, antiHBe, HBsAg,

Address for correspondence:

MUDr. Klaudia Pecova, Dept of Dermatovenerology Jessenius Faculty of Medicine in Martin, Comenius University in Bratislava, University Hospital in Martin (03601), Kollarova 2, Slovakia: e-mail: klaudiapec@gmail.com 
Cytomegalovirus, have been detected. Radiographs of sternoclavicular joints and abdominal ultrasonography were without pathological findings. The therapy of azathioprine was discontinued, by administration of the intravenous clindamycin (1.8mg/day for 14 days) with methylprednisolone $(0.5-1 \mathrm{mg} / \mathrm{kg} /$ day) and continuous administration of infliximab. Three weeks later, isotretinoin $0.2 \mathrm{mg} / \mathrm{kg} /$ day was administered, increased to $0.75 \mathrm{mg} / \mathrm{kg} /$ day. Followed 1 month oral clindamycin $(900 \mathrm{mg} /$ day) therapy, then ciprofloxacin (1g/day) for 4 weeks. The methylprednisolone and isotretinoin were gradually reduced to zero for a period of 1 year. Therapy of infliximab has been continuing up to now, with complete $\mathrm{CD}$ and $\mathrm{AF}$ remission.

\section{DISCUSSION}

Acne fulminans is characterized by multiple confluent sterile abscesses, evolving into the hemorrhagic necrosis on the face, neck and back, histologically usually with the signs of leucocytoclastic vasculitis. The fever, malaise, myalgias, arthralgias, active arthritis, increased erythrocyte sedimentations rate, leukocytosis (leukemoid reaction), positivity of inflammatory markers, microscopic haematuria accompanied aseptic, osteomyelitis-like and osteolytic lesions sternoclavicular joints, associated with erythema nodosum have been reported $(1,3,4)$. The EBV positivity has been discussed.

\section{CONCLUSIONS}

Combination of methylprednisolone and isotretinoin seems to be the most successful AFtherapy. The AF treatment with oral prednisolone $(0.5-1.0 \mathrm{mg} / \mathrm{kg} /$ day) is required (then gradually reduced to zero within the following 6-8 weeks). Oral isotretinoin should be then administered 4-6 weeks after the prednisolone therapy initiation (2). The both attacks of recurrent $\mathrm{AF}$ have occured in association with $\mathrm{CD}$ progression. The second attack of $\mathrm{AF}$ was in connection with the side-effect of above mentioned treatment or, as the paradoxical response induced by infliximab (5).

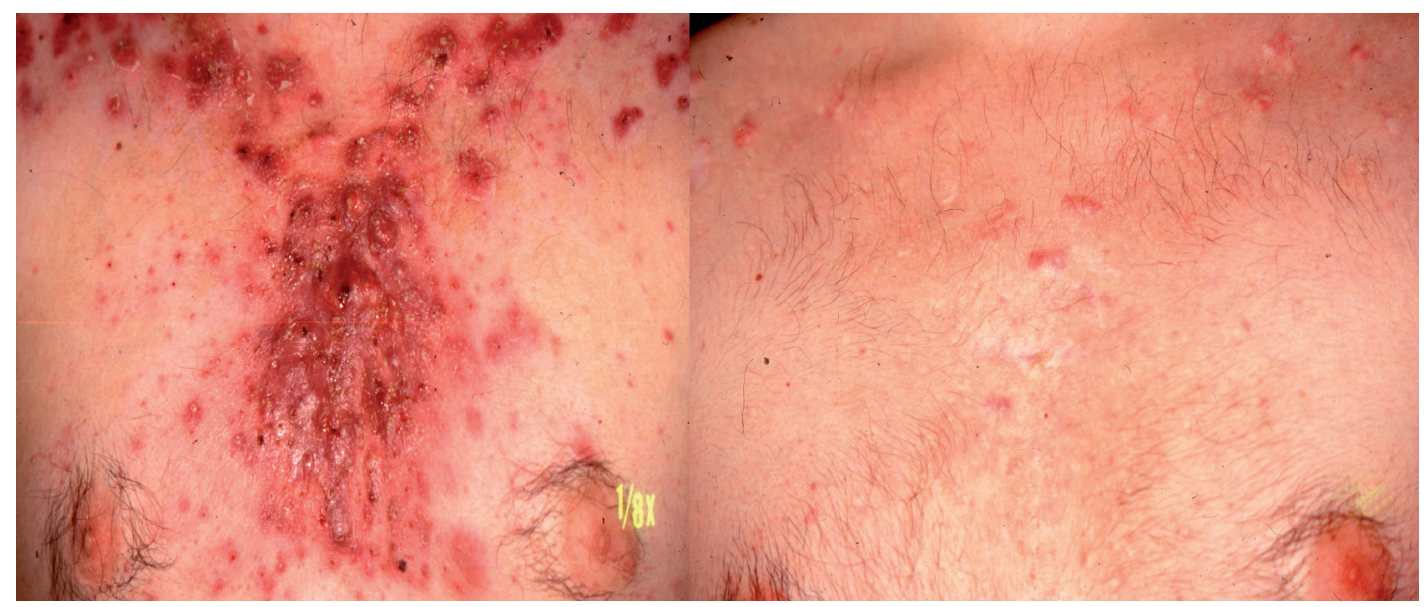

Figs.1,2 The second episode of AF. Multiple cultivation sterile abscesses (sternal area) and after the treatment (methylprednisolon and isotretinoin) 
Table 1. The biochemical parameters of $\mathrm{AF}$

\begin{tabular}{|l|c|c|c|}
\hline Parameters & 1st AF-attack & 2nd AF-attack & Remission \\
\hline ESR/1hour ${ }^{1}$ & 82 & 34 & 8 \\
\hline CRP $(<5.0 \mathrm{mg} / \mathrm{l})$ & 86.7 & 100.9 & 4.7 \\
\hline Le (3.9-10.0 10 9/1) & 15.2 & 16.1 & 7.6 \\
\hline Ly (25.0-46.0 \%) & 19.6 & 10.2 & 26.2 \\
\hline Tr (140-400 10 9/1) & 352 & 621 & Negative \\
\hline ANA & $1: 160$ & $1: 40$ & Negative \\
\hline p-ANCA & $1: 40$ & $1: 40$ & 15.6 \\
\hline RF (<14.0 U/ml) & 28.0 & 34.1 & 5.1 \\
\hline Fe (12.5-32.2 umol/1) & 8.0 & 2.3 & 138 \\
\hline Hb (140-179 g/l) & 103 & 112 & 0.43 \\
\hline HTK (0,39-0,54) & 0.31 & 0.35 & 62.9 \\
\hline Neutroph. (45.0-72.0 \%) & 79 & 82.5 & Negative \\
\hline EBV (PCR) copies/ml & & 1835 & \\
\hline
\end{tabular}

ESR=Erythrocyte sedimentation rate; $\mathrm{CRP}=\mathrm{C}$-reactive protein; Le= total white blood cells; Ly=lymphocytes \%; Tr= platelet; ANA=antinuclear antibodies; $p$-ANCA=perinuclear antineutrophil cytoplasmic antibodies; $\mathrm{RF}=$ rheumatic factor; $\mathrm{Fe}=$ serum iron; $\mathrm{Hb}=$ haemoglobin; $\mathrm{HTK}=$ haematocrit; $\mathrm{EBV}=$ Epstein-Barr virus

\section{REFERENCES}

1. Plewig G. Acne and Rosacea. 993 - 1017. In: Burgdorfer WHC, Plewig G, Wolff HH. Landthaler M. Braun-Falco s Dermatology. 3rd ed., Springer Medizin Verlag, Heidelberg, 2009: 1712.

2. Karvonen SL, Rasanen L, Cunliffe WJ, at al. Delayed hypersensitivity to Propionibacterium acnes in patients with severe nodular acne and acne fulminans. Dermatology 1994: 189: 344-349.

3. Mehrany K, Kist JM, Weenig RH, et al. Acne fulminans. Int J Dermatol 2005: 44: 132-133.

4. Williamson DM, Cunliffe WJ, Gatecliff M, et al. Acute ulcerative acne conglobata (acne fulminans) with erythema nodosum. Clin Exp Dermatol 1977: 2: 351-354.

5. Bassi E, Poli F, Chaeachon A, et al. Infliximab-induced acne: report of two cases. Br J Dermatol 2007: 156: 402-403. 